\title{
Study on distribution of Pro12Ala single nucleotide polymorphism of PPAR 2 gene in randomly sampled diabetic population from Guwahati city
}

\author{
Navaneeta Majumdar, ${ }^{1}$ Ananya Bhowmick, ${ }^{1}$ Purabi Sarkar, ${ }^{1}$ Rhituraj Doley, ${ }^{2}$ Indrajit Kalita, ${ }^{3}$ Subhash S. Medhi, ${ }^{2}$ \\ Sofia Banu ${ }^{1}$ \\ ${ }^{1}$ Department of Bioengineering and Technology, Gauhati University, Guwahati - 14; ${ }^{2}$ Department of Biological Sciences, \\ Gauhati University, Guwahati - 14; ${ }^{3}$ Shristi Diagnostics, Jonali, Guwahati - 24, India
}

\begin{abstract}
Diabetes is one of the most fatal and vastly heritable metabolic disorders across the globe primarily due to the associated long-term effects including uncontrolled blood sugar levels, blindness, renal and cardiac problems. One of the diabetes related genes peroxisome proliferated activated receptor gamma $2(P P A R \gamma 2)$ plays significant role in insulin metabolism and is expressed predominantly in adipose tissues. Single nucleotide polymorphism (SNPs) like Pro12Ala, is known to be associated with PPAR 2 gene. In this study, we have made an effort to investigate the prevalence of Pro12Ala allele in the diabetic population of Guwahati, Assam. A total of 50 human subjects with control subjects were included in the study. The data obtained revealed that 49 out of 50 samples carried the Pro/Pro allele, while 1 individual carried the Pro/Ala allele. Results obtained in the study indicate the existence of insignificant link between the targeted SNP Pro12Ala and type 2 diabetes in the sampled population, whereas in contrast we found a strong association of the SNP Pro12Pro with diabetes. The present study shows that there is a need to carry out an extensive study with a large population, which would give us the better picture of occurrence of this SNP in Northeast Indian population.
\end{abstract}

Correspondence: Sofia Banu, Department of Bioengineering and Technology, Gauhati University, Guwahati, 781014 Assam, India.

Tel.: 0361.2672233 - Fax: 0361.2700311.

E-mail: sofiabanu2@gmail.com

Key words: Insulin metabolism; PPAR 2; Pro12Ala; basal metabolic index; mutation; obesity.

Acknowledgments: the authors thank the Vice Chancellor of Gauhati University, Guwahati, Assam for his constant enthusiasm and support. We would also like to extend our thanks to Head of the Bioengineering and Biotechnology Department and Head of Biological Sciences Department, Gauhati University, Institute of Science and Technology, for providing scientific facilities to carry out the research work.

Contributions: NM, RD, experimental work; IK, samples providing and patients recording; $\mathrm{AB}, \mathrm{PS}$, manuscript drafting; SSM, infrastructural support to carry out the experiments; SB, study design, data analysis, financial and other infrastructural support.

Conflict of interest: the authors declare no potential conflict of interest.

Received for publication: 7 November 2013.

Revision received: 16 December 2013.

Accepted for publication: 14 January 2014.

This work is licensed under a Creative Commons Attribution NonCommercial 3.0 License (CC BY-NC 3.0).

CCopyright N. Majumdar et al., 2015

Licensee PAGEPress, Italy

Italian Journal of Medicine 2015; 9:157-162

doi:10.4081/itjm.2014.447

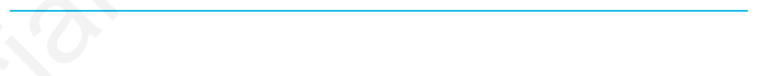

\section{Introduction}

In the present scenario diabetes is the most prevalent and highly heritable disorder globally. The World Health Organization (WHO) came to a decision of establishing World Congress in India, primarily because one diabetic person out of four globally, is Indian. According to the WHO projections, the 30 million to 33 million diabetic patients in India will shoot up to 40 million by 2010 and 74 million by $2025 .{ }^{1}$ WHO has declared a forewarning in 2012 that India will be the diabetes capital of the world by $2025 .^{2}$ In both, type 1 and type 2 diabetes, blood sugar levels, blood pressure and blood fats must be well monitored to prevent possible development of blindness, renal failure, and cardiac complications. ${ }^{3,4}$ Several genes have been found to be related to type 2 diabetes like TCF7L2, PPAR 2 , KCNJ11, CAPN10, TNF $\alpha$, RRAD, IGFBP5, INSIG1 and NGFI-B, out of which PPAR 2 has the most significant role to play. 5,6

Peroxisome proliferated activated receptor gamma $2(P P A R \gamma 2)$ is a transcription factor that belongs to the same family of nuclear receptors like steroid and thyroid hormone receptors, ${ }^{7}$ and is expressed predominantly in adipose tissues. Its action is triggered by certain fatty acids, prostanoids, and anti-diabetic agents like thiazolidinediones. ${ }^{8}$ After activation, it heterodimerizes with the retinoid $\mathrm{X}$ receptor and binds to specific 
PPAR-responsive elements of DNA to facilitate transcription of several target genes. ${ }^{9}$ The isoform PPAR 1 is ex-pressed in most of the tissues, but the PPAR 2 is specific for adipose tissue, where it plays a critical role in regulating adipogenesis and insulin functioning. ${ }^{10}$ The PPAR 2 gene is located on chromosome 3, and the specific isoforms are produced due to the result of alternative mRNA splicing. Quite a few genetic variants in the PPAR 2 gene have been identified which include Pro115Gln, Val290Met, Pro467Leu and the highly prevalent Pro12Ala polymorphism in PPAR $2 .{ }^{11,12}$ The Pro12Ala polymorphism is the result of a CCA-to-GCA missense mutation in codon 12 of exon $\mathrm{B}$ of the PPAR $\gamma 2 .{ }^{13}$ Single nucleotide polymorphism (SNPs) related to $P P A R \gamma 2$ gene have been reported on certain populations from Europe, North America and in Asia, ${ }^{11,14,15}$ and SNP like Pro12Ala have been found to be well associated with PPAR 2 gene.

Genome-wide association studies (GWAS) have immensely enhanced our understanding of the genetic basis of T2D. Most of the GWAS studies related to genes implicated in T2D have been reported from European, Chinese and African populations. ${ }^{16-19}$ Such GWAS studies, ${ }^{20,21}$ are found to be very limited in case of Indian population, though it is among the countries having the highest diabetic population, ${ }^{16}$ the situation is more negligible for Northeast Indian population where many ethnic tribes and communities exist. In India, the occurrence of type 1 is considerably more uncommon, and only about $1 / 3$ of type 2 diabetics are overweight. Diabetes is also beginning to appear much earlier in the lifespan of Indians, ${ }^{22}$ meaning that chronic long-term complications are becoming more common. But in the Northeast zone of India the prevalence of such SNPs in relation to type 1 or 2 diabetes has not been reported so far. If such data are generated then it will be statistically easier to determine its distribution along with its function and characteristics in Northeast Indian population and thus, will be helpful in drug administration. The present study is a preliminary investigation to lay the foundation for GWAS studies for PPAR 2 SNPs implicated to be indicative in type 2 diabetics in Northeastern population.

\section{Materials and Methods}

For the study, $2 \mathrm{~mL}$ of blood were collected from 50 subjects and from one control subject with assistance from Shristi Diagnostic center, Jonali, Guwahati $\left(26.1833^{\circ} \mathrm{N}, 91.7333^{\circ} \mathrm{E}\right)$, Assam, India under the supervision of a pathologist. Blood samples from diabetic patients regularly monitoring blood glucose level in the diagnostic center were chosen for the study. The datasheet for each sample prepared included age, sex, weight, height and fasting glucose. For each patient the basal metabolic index (BMI) was calculated using the formula: BMI=weight $(\mathrm{kg}) /$ height $(\mathrm{m})$ (Table 1).

DNA from blood was extracted through phenolchloroform extraction, ${ }^{23}$ and quantified using Nanodrop Quantifier (Thermo Fisher Scientific Inc., Wilmington, DE, USA). The DNA was used as template for polymerase chain reaction (PCR) using primers designed specifically for identifying the Pro12Ala mutation. Three primers were designed for the amplification purpose of our targeted gene sequence through Primer3. The primer sequences used in the study are shown in Table 2.

Amplifications were performed in a total reaction of $30 \mu \mathrm{L}$ containing: $2.5 \mu \mathrm{L}$ dNTPs $(8 \mathrm{mM}), 0.3 \mu \mathrm{L}$ Taq DNA polymerase $(5 \mathrm{U} / \mu \mathrm{L}), 3.0 \mu \mathrm{L} 10 \times$ buffer with $15 \mathrm{mM} \mathrm{MgCl} 2,2.0 \mu \mathrm{L}$ Primer $(10 \mathrm{mM}), 2.0 \mu \mathrm{L}$ Template DNA $(50 \mathrm{ng} / \mu \mathrm{L})$ and up to $30 \mu \mathrm{L} \mathrm{H}_{2} \mathrm{O}$. PCR amplification was programmed to complete 30 cycles after an initial denaturation cycle for $2 \mathrm{~min}$ at $94^{\circ} \mathrm{C}$. Each cycle consisted of a denaturation step at $94^{\circ} \mathrm{C}$ for $30 \mathrm{~s}$, an annealing step at $44^{\circ} \mathrm{C}$ for $45 \mathrm{~s}$ and an elongation step at $72^{\circ} \mathrm{C}$ for $90 \mathrm{~s}$. The primer extension segment was done for $7 \mathrm{~min}$ at $72^{\circ} \mathrm{C}$ in the final cycle. PCR-product of $15 \mu \mathrm{L}$ was resolved in $1.5 \%$ agarose gel electrophoresis with $1 \times$ TAE running buffer. Of the three primers used for the study, primers TD1F and TD1R produced a reproducible amplicon. Hence, the PCR was carried out with all the samples collected with the primers TD1F and TD1R and the product was sent for capillary sequencing to Macrogen Korea (Seoul, Korea).

\section{Results}

The PCR conditions for the three sets of primers used for amplicons production are shown in Table 3 and out of these three sets the TD1F and TDIR were found to be more efficient in amplification of the DNA.

\section{Sequence analysis}

To see the distribution of this SNP in our samples we performed DNA sequencing. The amplicons upon sequencing produced sequences of readable length of $751 \mathrm{bp}$. Figure 1 shows the representative chromatogram of the control sample and the mutated case sample.

\section{Statistical analysis}

We begin our analysis with the hypothesis that there is no relationship between type 2 diabetes and obesity in the sampled population. For the sampled data, along with allelic and genotypic frequency statistical analysis was also performed to find the relation between diabetes and obesity through Chi-square test. The Chi-square test for the samples is shown in Table 4. Association analysis of the SNP with type 2 diabetes was done by Chi-square test after adjustment for BMI. 
Table 1. Clinical characteristics of the sample set.

\begin{tabular}{|c|c|c|c|c|}
\hline $\begin{array}{l}\text { Sample } \\
\text { no. }\end{array}$ & Gender & $\begin{array}{c}\text { Age } \\
\text { in years }\end{array}$ & $\begin{array}{l}\text { Glucose amount } \\
\text { (FBS) } \mathrm{mg} / \mathrm{L}\end{array}$ & BMI \\
\hline 1. & Male & 58 & 178 & 30.4 \\
\hline 2. & Male & 34 & 185 & 32.4 \\
\hline 3. & Male & 56 & 189 & 28.3 \\
\hline 4. & Female & 66 & 170 & 28.5 \\
\hline 5. & Female & 64 & 177 & 26.5 \\
\hline 6. & Female & 69 & 148 & 35.1 \\
\hline 7. & Female & 62 & 107 & 37.3 \\
\hline 8. & Female & 68 & 142 & 28.0 \\
\hline 9. & Male & 52 & 94 & 31.7 \\
\hline 10. & Male & 49 & 99 & 30.5 \\
\hline 11. & Male & 30 & 106 & 31.4 \\
\hline 12. & Female & 52 & 93 & 26.9 \\
\hline 13. & Female & 66 & 152 & 27.6 \\
\hline 14. & Male & 61 & 194 & 24.4 \\
\hline 15. & Male & 69 & 161 & 24.8 \\
\hline 16. & Male & 47 & 178 & 31.5 \\
\hline 17. & Male & 66 & 242 & 30.7 \\
\hline 18. & Male & 62 & 132 & 31.4 \\
\hline 19. & Female & 61 & 108 & 35.1 \\
\hline 20. & Female & 40 & 142 & 27.4 \\
\hline 21. & Male & 58 & 247 & 29.6 \\
\hline 22. & Female & 50 & 294 & 30.4 \\
\hline 23. & Female & 55 & 158 & 34.5 \\
\hline 24. & Female & 68 & 113 & 24.5 \\
\hline 25. & Female & 74 & 107 & 30.9 \\
\hline 26. & Male & 50 & 110 & 29.6 \\
\hline
\end{tabular}

\begin{tabular}{|c|c|c|c|c|}
\hline $\begin{array}{l}\text { Sample } \\
\text { no. }\end{array}$ & Gender & $\begin{array}{c}\text { Age } \\
\text { in years }\end{array}$ & $\begin{array}{l}\text { Glucose amount } \\
\text { (FBS) } \mathrm{mg} / \mathrm{L}\end{array}$ & BMI \\
\hline 27. & Female & 70 & 104 & 31.4 \\
\hline 28. & Female & 48 & 115 & 33.0 \\
\hline 29. & Female & 41 & 94 & 32.9 \\
\hline 30. & Male & 53 & 143 & 31.9 \\
\hline 31. & Female & 30 & 107 & 26.8 \\
\hline 32. & Male & 44 & 116 & 31.9 \\
\hline 33. & Female & 61 & 143 & 34.5 \\
\hline 34. & Male & 68 & 84 & 25.0 \\
\hline 35. & Female & 40 & 404 & 29.0 \\
\hline 36. & Male & 56 & 104 & 26.5 \\
\hline 37. & Female & 55 & 153 & 28.7 \\
\hline 38. & Female & 55 & 153 & 35.2 \\
\hline 39. & Female & 53 & 151 & 31.0 \\
\hline 40. & Female & 70 & 117 & 29.3 \\
\hline 41. & Female & 55 & 184 & 35.6 \\
\hline 42. & Female & 61 & 151 & 29.3 \\
\hline 43. & Female & 40 & 176 & 30.9 \\
\hline 44. & Female & 60 & 105 & 29.3 \\
\hline 45. & Female & 50 & 184 & 30.9 \\
\hline 46. & Male & 53 & 116 & 29.9 \\
\hline 47. & Female & 60 & 158 & 35.1 \\
\hline 48. & Female & 43 & 166 & 29.7 \\
\hline 49. & Female & 48 & 148 & 30.2 \\
\hline 50. & Male & 35 & 96 & 31.0 \\
\hline 51. & Male & 32 & 285 & 28.1 \\
\hline
\end{tabular}

FBS, fasting blood sugar; BMI, basal metabolic index.

Table 2. Primers used for initial screening.

\begin{tabular}{lcc}
\hline Primer pair & Genome type & Name \\
\hline 5'ACTGAACATGGGTCACCG3' & Human & TD1F \\
3'GGAATAAAAGTGCTGCAAGAGGG5' & TD1R \\
\hline 5'GGATATTGAACAGTCTCTGC3' & Human & TD5F \\
3'CCTTCAAGTCTAAAAAAGCCC5' & TD5R \\
\hline 5'ATTCAACCAGGAATAGACACC3' & Human & TD8F \\
3'AAAAGTGACCCTTCAAGTCT5' & & TD8R \\
\hline
\end{tabular}

Table 3. Polymerase chain reaction amplification conditions for the three set of primers.

\begin{tabular}{lcc}
\hline Primer set & Annealing temperature and time & PCR amplicons produced \\
\hline TD1F and TD1R & $61.9^{\circ} \mathrm{C}$ for $40 \mathrm{~s}$ & ++++ \\
\hline TD5F and TD5R & $56.7^{\circ} \mathrm{C}$ for $40 \mathrm{~s}$ & ++ \\
\hline TD8F and TD8R & $55.3^{\circ} \mathrm{C}$ for $40 \mathrm{~s}$ & ++ \\
\hline
\end{tabular}

PCR, polymerase chain reaction. 
As a result, we found that the critical $\mathrm{P}$ value $(0.05)$ is less than the observed value $(0.1<\mathrm{P}<0.5)$ (Table 5), which means that our hypothesis regarding the nonrelativeness of the obesity with type 2 diabetes is false.

\section{Discussion and Conclusions}

Several recent studies have demonstrated that PPAR 2 gene is significantly related to type 2 and type 1 diabetes in humans. ${ }^{24,25}$ The importance of this gene, which is present in human chromosome number 3 , is due to the presence of SNP Pro12Ala. Population study in Europe, Africa and some parts of Asia revealed that these SNP's may be responsible for obesity leading to type 2 diabetes. ${ }^{26-28}$ But all the results were not affirmative. ${ }^{29}$ In the previous studies, T2D subjects were found to possess a significantly higher frequency of the Pro12 allele risk than non-diabetic controls, thus providing a supportive role for PPAR 2 in the genetic risk for type 2 diabetes in French Caucasians. ${ }^{30}$ So, we hypothesized that diabetic population in Guwahati city is not related to obesity. The total study subjects were 50 along with a control. But out of 50 only one sample was found homozygously mutated (Pro12Pro), though 30 of them were highly obese (data not shown). By Chi-square test the $\mathrm{P}$ value was found to be 0.05 . By sampling out 50 diabetic samples along with the control and calculating their BMI, we found that our $\mathrm{P}$ $(0.16)$ value is much greater than the statistically standardized critical $P$ value (0.05). Thus, our hypothesis became null and concluded that most of the diabetic people are obese. That means the SNP Pro12Ala which is associated with obesity has got modest but significant role in susceptibility to type 1 and type 2 diabetes. But after finding the genotypic (0.98 and $0.02)$ (Table 6) and allelic frequency (0.98 and 0.02) of the control and the samples respectively, it is seen that the SNP Pro12Ala does not have a significant im-
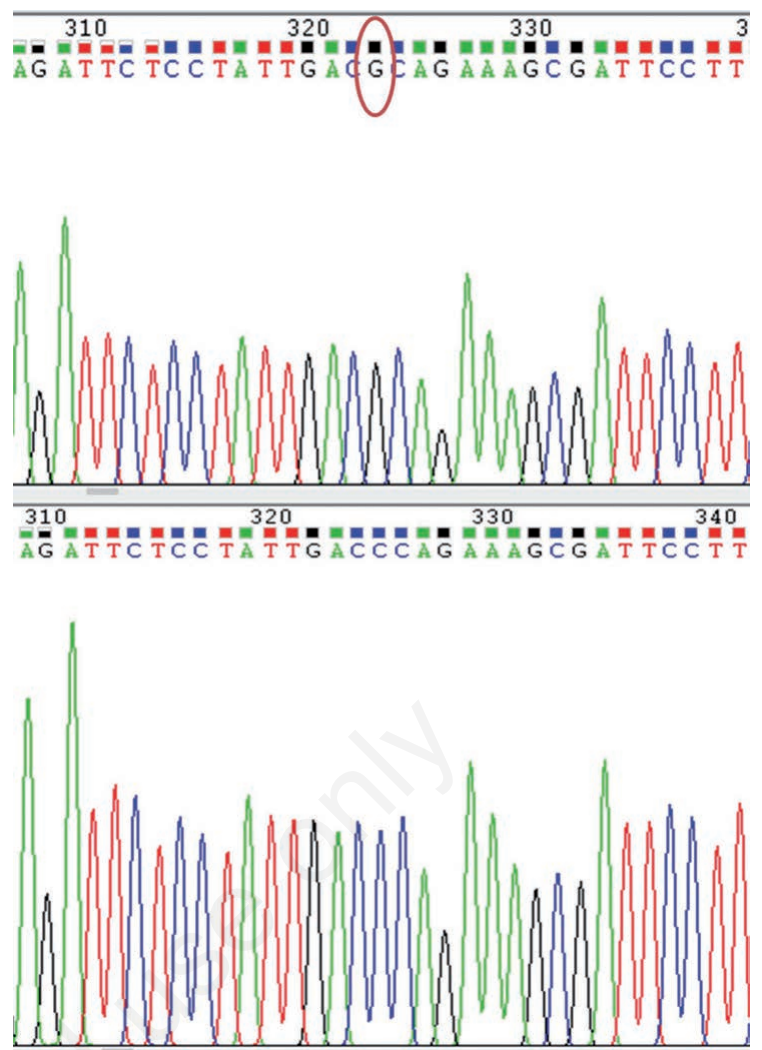

Figure 1. Chromatogram depicting the single nucleotide polymorphism in mutated and control sample.

Table 4. Chi-square test for the samples.

Obese diabetic Non-obese diabetic Total

\begin{tabular}{llll}
\hline Observed & 30 & 20 & 50 \\
\hline Expected & 25 & 25 & 50 \\
\hline
\end{tabular}

Chi-square value $=1.9602 ; \mathrm{P}=0.1<\mathrm{P}<0.5$.

Table 5. Single nucleotide polymorphism Pro12Ala having significant link with type 2 diabetes.

\begin{tabular}{lccccc}
\hline Gene & SNP & Frequency of case subjects & Risk allele control subject & Risk/non-risk allele & $\begin{array}{c}\text { P value } \\
(\mathbf{P}=\mathbf{0 . 0 5})\end{array}$ \\
\hline PPAR 2 & $\begin{array}{r}\text { rs1801282 } \\
\text { Pro12Ala }\end{array}$ & 0.98 & 0 & $\mathrm{C} / \mathrm{G}$ & $0.1<\mathrm{P}<0.5$
\end{tabular}

SNP, single nucleotide polymorphism.

Table 6. PPAR $\gamma 2$ genotype frequencies in the study group.

\begin{tabular}{lccc}
\hline Types & Pro12Pro (wild-type) $\mathbf{C} / \mathbf{C}$ & Pro12Ala (heterozygote) $\mathbf{C} / \mathbf{G}$ & Ala12Ala (homozygote) G/G \\
\hline Case samples & 0.98 & 0.00 & 0.02 \\
\hline Control sample & 1 & - & - \\
\hline
\end{tabular}


pact on type 2 diabetes and hence it follows HardyWeinberg's equilibrium theory. Out of 50 samples only 1 male individual was found to be mutated $(\mathrm{CCA} / \mathrm{GCA}$, BMI=31.4), so it was considered insignificant (data not shown). Thus, from the sequencing result we can say that although in some population this SNP Pro12Ala might have shown some significant association with obesity and type 2 diabetes, but within Guwahati city, it does not have any such impact. It is also possible that there might be some errors because of small sample number and random sampling. ${ }^{31}$ So, for a better and clear understanding we need to have a large number controls as well as case samples. Thus, like in the European countries, ${ }^{11,31,32}$ we were also unable to find any significant link of this SNP Pro12Ala with type 2 diabetes in Guwahati city. Our results show that the Pro12Ala polymorphism is not associated with obesity in the diabetic population of Guwahati city. The results show that 49 individuals out of 50 samples carried the Pro/Pro allele that is (C to $\mathrm{C}$ mutation at ID rs1801282), while 1 individual carried the Pro/Ala allele (C to $\mathrm{G}$ mutation at ID rs1801282). Till date, no published data are available on the distribution of the Pro/Ala SNP in the diabetic population of Assam. This study is a pilot scale attempt with a small population to understand the prevalence of the SNP in the urban diabetic population. The study was carried out with a secondary aim to elucidate if any link exists between the type 2 diabetics (BMI being an indicator) and the SNP. The results obtained indicated that there is a very insignificant link between the targeted SNP Pro12Ala and type 2 diabetes, but in contrast we found a strong association of the SNP Pro12Pro with diabetes. Hence, though the Hardy-Weinberg's equilibrium theory is not violated, owing to small dataset affirmative conclusion cannot be drawn from the study. However, the results obtained in the study provide the preliminary overview and emphasize the need to have an extensive analysis with a large dataset containing diabetics as well as non-diabetic population. Such a study would provide in depth analysis and will help to elucidate the frequency of existence of this SNP in Northeast India. As Northeast India is hub of many ethnic communities and tribes, understanding this polymorphism may help us in enhanced diagnosis, prevention, and therapeutic approaches toward a more systematic management of type 2 diabetes in different communities.

\section{References}

1. Ban HJ, Heo JY, Oh KS, Park KJ. Type 2 diabetes-associated combination of SNPs using support vector machine. BMC Genet 2010;26:1-11.

2. Magon N. Gestational diabetes mellitus: get, set, go from diabetes capital of the world to diabetes care cap- ital of the world. Indian J Endocrinol Metab 2011;15: 161-9.

3. Jesmin J, Rashid MS, Jamil H, et al. Gene regulatory network reveals oxidative stress as the underlying molecular mechanism of type 2 diabetes and hypertension. BMC Med Genomics 2010;3:45.

4. Hovnik T, Dolzan V, Bratina NU, et al. Genetic polymorphisms in genes encoding antioxidant enzymes are associated with diabetic retinopathy in type 1 diabetes. Diabetes Care 2009;32:2258-62.

5. Willer CJ, Bonnycastle LL, Conneely KN, et al. Screening of 134 single nucleotide polymorphisms (SNPs) previously associated with type 2 diabetes replicates association with 12 SNPs in nine genes. Diabetes 2007; 56:256-64.

6. Wu X, Wang J, Cui X, et al. The effect of insulin on expression of genes and biochemical pathways in human skeletal muscle. Endocrine 2007;3:5-17.

7. Stumvoll M, Häring H. The peroxisome proliferator-activated receptor-2 Pro12Ala polymorphism. Diabetes 2002;51:2341-7.

8. Oliver Jr WR, Shenk JL, Snaith MR, et al. A selective peroxisome proliferator-activated receptor $\delta$ agonist promotes reverse cholesterol transport. Proc Natl Acad Sci 2001;98:5306-11.

9. Kershaw EE, Schupp M, Guan HP, et al. PPAR $\gamma$ regulates adipose triglyceride lipase in adipocytes in vitro and in vivo. Am J Physiol Endocrinol Metab 2007; 293:E1736-45.

10. Goto T, Lee JY, Teraminami A, et al. Activation of peroxisome proliferator-activated receptor- $\alpha$ stimulates both differentiation and fatty acid oxidation in adipocytes. J Lipid Res 2011;52:873-4.

11. Ludovico O, Pellegrini F, Di Paola R, et al. Heterogeneous effect of peroxisome proliferator-activated receptor $\gamma 2$ Ala12 variant on type 2 diabetes risk. Obesity 2007;15:1076-81.

12. Eftychi C, Howson JM, Barratt BJ, et al. Analysis of the type 2 diabetes-associated single nucleotide polymorphisms in the genes IRS, KCNJ11 and PPAR $\gamma 2$ in type 1 diabetes. Diabetes 2004;53:870-3.

13. Namvaran F, Moghaddama PR, Azarpira N. Genotyping of peroxisome proliferator-activated receptor gamma (PPAR- $\gamma$ ) polymorphism (Pro12Ala) in Iranian population. J Res Med Sci 2011;16:291-6.

14. Sanghera DK, Demirci FY, Been L, et al. PPAR $\gamma$ and ADIPOQ gene polymorphisms increase type 2 diabetes mellitus risk in Asian Indian Sikhs: Pro12Ala still remains as the strongest predictor. Metabolism 2010;59: 492-501.

15. Kooner JS, Saleheen D, Sim X, et al. Genome-wide association study in individuals of South Asian ancestry identifies six new type 2 diabetes susceptibility loci. Nature Genet 2011;43:921-89.

16. Tabassum R, Chauhan G, Dwivedi OP, et al. Genomewide association study for type 2 diabetes in Indians identifies a new susceptibility locus at 2 q21. Diabetes 2013;62:977-86.

17. McCarthy MI, Zeggini E. Genome-wide association studies in type 2 diabetes. Curr Diabetes Rep 2009;9: 164-71.

18. Sanghera DK, Blackett PR. Type 2 diabetes genetics: beyond GWAS. J Diabetes Metab 2012;3:6948. 
19. Billings LK, Florez JC. The genetics of type 2 diabetes: what have we learned from GWAS? Ann NY Acad Sci 2010;1212:59-77.

20. Saxena R, Saleheen D, Been LF, et al. Genome wide association - study identifies a novel locus contributing to type 2 diabetes susceptibility in Sikhs of Punjabi origin from India. Diabetes 2013;62:1746-55.

21. Gupta V, Vinay DG, Sovio U, et al. Association study of 25 type 2 diabetes related loci with measures of obesity in Indian Sib Pairs. PLoS One 2013;8:e53944.

22. Radha V, Mohan V. Genetic predisposition to type 2 diabetes among Asian Indians. Indian $\mathrm{J}$ Med Res 2007;125:259-74.

23. Chomczynski P, Sacchi N. Single-step method of RNA isolation by acid guanidinium thiocyanate-phenol-chloroform extraction. Anal Biochem 1987;162:156-9.

24. Tsukahara T, Haniu H, Matsuda Y. Effect of alkyl glycerophosphate on the activation of peroxisome proliferator-activated receptor gamma and glucose uptake in C2C12 cells. Biochem Biophys Res Commun 2013;433: 281-5.

25. Muller Y Li, Bogardus C, Beamer BA, et al. A functional variant in the peroxisome proliferator-activated receptor 2 promoter is associated with predictors of obesity and type 2 diabetes in Pima Indians. Diabetes 2003;52:1864-71.

26. Mattevi VS, Zembrzuski VM, Hutz MH. Effects of a
PPAR $\gamma$ gene variant on obesity characteristics in Brazil. Braz J Med Biol Res 2007;40:927-32.

27. Salonen JT, Uimari P, Aalto JM, et al. Type 2 diabetes whole-genome association study in four populations: the DiaGen Consortium. Am J Hum Genet 2007;81:338-45.

28. Unoki H, Takahashi A, Kawaguchi T, et al. SNPs in KCNQ1 are associated with susceptibility to type 2 diabetes in East Asian and European populations. Nat Genet 2008;40:1098-102.

29. Kao WH, Coresh J, Shuldiner AR, et al. Atherosclerosis risk in communities study, Pro12Ala of the peroxisome proliferator-activated receptor-2 gene is associated with lower serum insulin levels in nonobese African Americans. Diabetes 2003;52:1568-72.

30. Clement K, Hercberg S, Passinge B, et al. The Pro115Gln and Pro12Ala PPAR gamma gene mutations in obesity and type 2 diabetes. Int J Obes Relat Metab Disord 2000;24:391-3.

31. Ghoussaini M, Meyre D, Lobbens S, et al. Implication of the Pro12Ala polymorphism of the PPAR-gamma 2 gene in type 2 diabetes and obesity in the French population. BMC Med Genet 2005;6:1-8.

32. Ereqat S, Nasereddin A, Azmi K, et al. Impact of the Pro12Ala polymorphism of the PPAR-gamma 2 gene on metabolic and clinical characteristics in the Palestinian type 2 diabetic patients. PPAR Res 2009;87412:1-5. 